Egyptian Journal of Rabbit Science, 27 (2): 427- 446(2017)

\title{
UTILIZATION OF Ziziphus spina-christi LEAVES AS A NATURAL GROWTH PROMOTER IN RABBIT'S RATIONS.
}

M.M. Basyony; Hanim. A. Elsheikh.; Haiam. S. Abdel Salam; Kh. I. Mohamed and Afaf, H. Zedan.

Animal Production Research Institute, ARC, Giza, Egypt.

Ninety weaned New Zealand White (NZW) male rabbits at 6 weeks of age (mean initial body weight, (762.60g) were used to evaluate the potential of ziziphus spina-christi leaves (sidr) as natural growth promoters of growing rabbits. Rabbits were randomly assigned to three experimental groups ( $n=30$ in each group) in a simple randomized design experiment and fed individually during experimental period ( 8 weeks). The control group (diet 1) was fed a diet without Sider leaves (SL); the experimental groups were fed the same diet with 10 (diet 2), and $20 \mathrm{~g}$ SL/kg diet (diet 3). This was followed by 5 days of feeding as a collection period to determine nutrients digestibility of the tested diets.

Final live weight, total weight gains and average daily gain $(A D G)$ were significantly higher for diet $3(20 \mathrm{~g} \mathrm{SL} / \mathrm{kg}$ diet $)$ than for others. Rabbits fed control diet showed almost the lowest values $(P<0.05)$ of the digestibility of various feed components. It was observed that rabbits taking diet 3 had significantly higher $(P<0.05)$ TDN and DCP compared with those taking control diet. The best nitrogen balance $(P<0.05)$ recorded with rabbits fed diet 3 , which followed by those fed diet 2 and control diet $(0 \mathrm{~g} S L / K g$ diet), respectively. The $\mathrm{NH}_{3}-\mathrm{N}$ value of diet1 group was significantly $(P<0.05)$ higher compared with others. The total anaerobic bacteria count in control group was higher $(P<0.05)$ than others. However, rabbits of group 2 and 3 recorded the highest total anaerobic cellulolytic bacteria count values. Whereas, total protein levels in blood serum of rabbits fed diet 3 were significantly lower $(P<0.05)$ than that in the control group by $15.65 \%$, respectively. However, urea nitrogen, uric acid and creatinine values were also significantly $(P<0.05)$ higher in the control group than in group 3. Dressing 
percentages of slaughter rabbits improved significantly $(P<0.05)$ in diet 3 compared to the control group.

Conclusively, the results of this study could have provided scientific validity for the use of low ziziphus spina-christi leaves levels $(20 \mathrm{~g} \mathrm{SL} / \mathrm{kg}$ diet) in the growing rabbit diets as natural growth promoters without any adverse effects on rabbit performance.

Key words: ziziphus, rabbits, digestibility, growth promoter.

No doubt, that the veterinary medicine prices have become very expensive, especially antibiotics, growth promoters and vitamins, the price of fodder especially imported from abroad in Egypt Also, rabbit production is limited due to the high mortality and increased use of antibiotics has led to high incidence of resistant bacterial strains infections and associated with increased side effects. Rabbit meat is of high quality and safety; it is suitable to be raised for meat production due to its high feed conversion efficiency (De Blas and Garvey, 1975).

Gastrointestinal illnesses can cause death in 30-50\% of the stock, and the animal's performance can also significantly be reduced (Lelkes and Chang, 1987). For resolve these problems, it is necessary to use the growth promoters of natural origin, which are able to provide the comparable efficacy and will not contribute to the cumulative contamination of the environment (Bomba et $a l ., 2006)$. Finally, control of the micro-biota could limit digestive disorders around weaning via its barrier effect and its role as an immune stimulator (Combes et al., 2013). ziziphus spina-christi is a subtropical plant known in Egypt as 'Nabq' or 'Sidr' (Taeckholm, 1974) which is used for various medicinal purposes. The leaves provide valuable animal forage and fodder under open grazing conditions, but the nutritional value is apparently not high for most domestic livestock. The leaves contain various alcaloids, including ziziphine, jubanine and amphibine, alpha terpinol, linalol and diverse saponins. ziziphusspina-christi L. ziziphusspina - christi has been shown to have activity against bacteria and fungi (Abdel-Galil and El-Jissry., 1991).

Therefore, the objective of the present work was to study the effect of addition different levels of ziziphusspina-christi $L$. leaves as natural growth promoter to rabbit's diets, on growth performance, carcass traits, digestibility coefficients of nutrients, cecal content and blood biochemical characteristics of growing rabbits. 
UTILIZATION OF Ziziphus spina-christi LEAVES IN RABBIT'S RATIONS 429

\section{MATERIALS AND METHODS}

\section{Experimental design:}

This study was carried out at Borg El-Arab research station, Agricultural Research Center, Alexandria. Total 90 weaned New Zealand White (NZW) male rabbits at 6 weeks of age (mean initial body weight, $762.60 \mathrm{~g})$ were randomly assigned to three experimental groups ( $\mathrm{n}=30$ in each group) in a simple randomized design experiment. The control group was fed a diet without Sider leaves (SL) (diet 1); the experimental groups were fed the same diet with 10, and $20 \mathrm{~g} \mathrm{SL/kg}$ (diet 2 and diet 3, respectively). The experimental period lasted for 8 weeks (from 6 to 14 weeks of age).

\section{Experimental animals, housing and diets:}

Rabbits were individually housed in galvanized wire cages (dimensions: $30 \times 20 \times 35 \mathrm{~cm}$ ) under a 12:12 h light-dark cycle until marketing at 14 weeks of age. All rabbits were fed pelleted diet ad libitum. The experimental diets were formulated to meet the recommended nutrient requirements of growing rabbits according to Lebas (2004). The SL supplementation levels (10 and $20 \mathrm{~g}$ ) were pre-mixed with $1 \mathrm{~kg}$ of each diet and successively mixed into the remaining diet to obtain the homogenous inclusion level. All rabbits were kept under the same management, hygienic and environmental conditions. Rabbits were reared in a well-ventilated building; fresh water was automatically available all the time by stainless steel nipples fixed in each cage. Throughout the experimental period, body weight was determined every 2 weeks (at 6, 8, 10, 12 and 14 weeks of age) and average body weight gain was calculated. During the whole experimental period, the feed intake was determined precisely and is given as grams per rabbit per week. From each cage, feed residuals were collected daily, weighed and taken into consideration for the calculation of feed intake and feed conversion ratio. Feed ingredients and chemical composition of the experimental diet are shown in Tables 1 and 3.

Analysis of diets and sidr leaf were performed as recommended by AOAC (2000) for determining moisture, crude protein (CP), crude fiber $(\mathrm{CF})$, ether extract (EE), ash. The condensed tannins were determined according to Makkar (2003), phenolic compounds were determined using the high-performance liquid chromatographic using the procedure of Meier et al. 
(1988). The contents of phenolic contents in the sidr (ziziphusspina-christi) leaves used in the present study are presented in Table 2.

Table 1. The proximate chemical composition of ziziphus spina-Christi.

\begin{tabular}{|c|c|c|c|c|c|c|c|c|}
\hline $\begin{array}{c}\text { Chemical } \\
\text { composition }\end{array}$ & $\begin{array}{c}\text { Moisture } \\
\mathbf{\%}\end{array}$ & $\begin{array}{c}\text { CP } \\
\mathbf{\%}\end{array}$ & $\begin{array}{c}\text { EE } \\
\mathbf{\%}\end{array}$ & $\begin{array}{c}\text { CF } \\
\mathbf{\%}\end{array}$ & $\begin{array}{c}\text { Ash } \\
\mathbf{\%}\end{array}$ & $\begin{array}{c}\text { ADF } \\
\mathbf{\%}\end{array}$ & $\begin{array}{c}\text { Lignin } \\
\mathbf{\%}\end{array}$ & $\begin{array}{c}\text { Cellulose } \\
\mathbf{\%}\end{array}$ \\
\hline $\begin{array}{c}\boldsymbol{\%} \\
\text { DM basis) }\end{array}$ & 8.30 & 8.76 & 3.39 & 17.71 & 8.90 & 44.19 & 31.41 & 24.21 \\
\hline
\end{tabular}

Table 2. Phenolic contents of sidr (ziziphus spina-christi.) leaves.

\begin{tabular}{|l|c|}
\hline Items & Sidr (ziziphusspina-christi.) leaves \\
\hline Total phenols (ppm) & 717.00 \\
\hline Condensed tannin (\% on DM basis) & 3.17 \\
\hline
\end{tabular}

\section{Digestibility trials:}

At the end of the growth experiment (14 weeks of age) digestibility trials were carried out to determine the nutrients digestibility, feeding values and nitrogen balance of experimental diets. A total number of 15 male rabbits were taken randomly ( 3 with in each treatment) and allotted in different treatment. Animals were housed individually in cages that allowed the separation of feces and urine. All rabbits were kept under the same management, hygienic and environmental conditions. The experimental diets were offered twice daily at 9 a.m. and 15 p.m. and fresh water was provided ad libitum. Survey of daily feed consumption was recorded. Any possible feed contamination was removed from the feces. Samples of daily feces of each rabbit were taken and oven dried at $60^{\circ} \mathrm{C}$ for $48 \mathrm{~h}$, then was ground and stored for proximate chemical analysis. Samples of feed and feces were analyzed for DM, CP, EE, CF, and ash according to the classical A.O.A.C (2000) methods. The nutritive values of the experimental diets as total digestible nutrients (TDN) value were calculated according to Cheeke (1987). Digestible energy (DE) was calculated according to Fekete and Gippert (1986) using the following equation: DE $(\mathrm{kcal} / \mathrm{kg} \mathrm{DM})=4253-32.6(\mathrm{CF} \%)-144.4$ (total ash). The urine of each animal was collected in a glass recipient, containing $10 \mathrm{ml}$ of a $1: 1 \mathrm{HCl}: \mathrm{H} 2 \mathrm{O}$ solution, to avoid bacterial production and possible losses by volatilization. The values of nitrogen intake (NI), nitrogen excreted in feces (NF) and 
UTILIZATION OF Ziziphus spina-christi LEAVES IN RABBIT'S RATIONS 431

Table 3: Feed ingredients and chemical composition of experimental diets (\% DM basis).

\begin{tabular}{|c|c|c|c|}
\hline \multirow[b]{2}{*}{ Feed Ingredients (\%) } & \multicolumn{3}{|c|}{ Experimental diets, SL/kg } \\
\hline & $\begin{array}{l}\text { Diet1 } \\
(0.0 g)\end{array}$ & $\begin{array}{c}\text { Diet2 } \\
(\mathbf{1 0 . 0 g})\end{array}$ & $\begin{array}{c}\text { Diet3 } \\
(20.0 g)\end{array}$ \\
\hline Soybean meal $(44 \% \mathrm{CP})$ & 20.9 & 20.9 & 20.9 \\
\hline Barley & 32 & 32 & 32 \\
\hline Wheat bran & 9.2 & 9.2 & 9.2 \\
\hline berseem hay & 31 & 30 & 29 \\
\hline Molasses & 3 & 3 & 3 \\
\hline Limestone & 0.7 & 0.7 & 0.7 \\
\hline Di- Ca- phosphate & 2.2 & 2.2 & 2.2 \\
\hline DL-Methionine & 0.4 & 0.4 & 0.4 \\
\hline $\mathrm{NaCl}$ & 0.3 & 0.3 & 0.3 \\
\hline Vit.-Min. premix* & 0.3 & 0.3 & 0.3 \\
\hline Ziziphus spina-christi L. leaves & 0.0 & 1.0 & 2.0 \\
\hline Total & 100 & 100 & 100 \\
\hline \multicolumn{4}{|l|}{ Chemical composition (\%DM basis) } \\
\hline DM & 92.88 & 92.78 & 91.98 \\
\hline $\mathrm{OM}$ & 90.88 & 90.68 & 90.59 \\
\hline $\mathrm{CP}$ & 17.56 & 17.37 & 17.35 \\
\hline $\mathrm{CF}$ & 13.46 & 13.45 & 13.46 \\
\hline $\mathrm{EE}$ & 2.3 & 2.29 & 2.35 \\
\hline NFE & 57.65 & 57.57 & 57.43 \\
\hline Ash & 9.120 & 9.320 & 9.410 \\
\hline $\mathrm{NDF}$ & 37.767 & 37.761 & 37.767 \\
\hline Digestible energy $(\mathrm{Kcal} / \mathrm{Kg} \mathrm{DM})^{* *}$ & 2497.27 & 2468.72 & 2455.4 \\
\hline
\end{tabular}

*Mineral and vitamin mixture supplied per kg of diet: Vitamin A 10,000 IU, Vitamin D3,1,800 UI; Vitamin E, $15 \mathrm{mg}$; Vitamin K3, $4.5 \mathrm{mg}$; Vitamin B1, $0.5 \mathrm{mg}$; Vitamin B2, $4 \mathrm{mg}$; Vitamin B12, $0.001 \mathrm{mg}$; Folic acid, $0.1 \mathrm{mg}$; Pantothenic acid, $7 \mathrm{mg}$; Nicotinic acid, $20 \mathrm{mg}$; I, $1 \mathrm{mg}$; Mn, $60 \mathrm{mg}$; Cu, $5.5 \mathrm{mg}$, Zn, $75 \mathrm{mg}$; Fe, $40 \mathrm{mg}$; Co, $0.3 \mathrm{mg}$; Se, $0.08 \mathrm{mg}$; Robenidine, $52.8 \mathrm{mg}$, Antioxidant, $0.250 \mathrm{mg}$.

**Digestible energy (DE) was calculated according to Fekete and Gippert (1986) using the following equation: $\mathrm{DE}(\mathrm{kcal} / \mathrm{kg} \mathrm{DM})=4253-32.6$ (CF \%)-144.4 (total ash).

nitrogen excreted in urine (NU) were obtained by the amounts of feed ingested and excreted nitrogen of feces and urine, respectively, retained nitrogen was calculated as $\mathrm{RN}=\mathrm{NI}-(\mathrm{NF}+\mathrm{NU})$. 


\section{Slaughtering and carcass traits:}

At the end of period of growth experiment, five male rabbits from each group (aged 14 weeks) were randomly taken, fasted for $12 \mathrm{~h}$, individually weighed and immediately slaughtered. After complete bleeding, pelt, viscera and tail were removed, and then the carcass and its components were weighed as edible parts. The non-edible parts including lung, spleen, stomach, large intestine, small intestine and kidney fat were also weighed as percentage of pre-slaughter weight. Dressing percentage was calculated by dividing the hot dressed carcass weight by pre-slaughter weight and expressed as a percentage. Gastrointestinal tracts were individually removed from three slaughtered rabbits from each group, the cecum was weighted and the $\mathrm{pH}$ of the caecal content was measured using digital pH meter (Orion Research Digital pH meter, model 201). Then the caecal content was collected and divided into two samples, one of them was taken to estimate the cecum microflora (Total anaerobic bacteria count and anaearobic cellulolytic bacteria count) determined by Standard method according to Kim and Goepfert (1971). Using nutrient agar medium (Difco Manual, 1984), another sample was filtered through four folds of gauze for determination of total volatile fatty acids (VFA) and ammonia nitrogen by steam distillation (UDK 139- Semi-Automatic Distillation Unit) according to Warner (1964).

\section{Blood samples and determination of biochemical parameters:}

For determining blood biochemical components, five blood samples ( $5 \mathrm{ml}$ from each rabbit) were taken during slaughter from five animals per treatment. Plasma was separated from blood by centrifugation at $1000 \mathrm{~g}$ for $20 \mathrm{~min}$ and stored at $-20^{\circ} \mathrm{C}$ till assayed. Plasma total protein, albumin, glucose, urea nitrogen, uric acid and creatinine were measured calorimetrically using commercial kits (purchased from Bio-diagnostic, Cairo, Egypt) according to the manufacturers' instructions. Total protein was determined according to Orsonneau et al. (1989). Albumin was determined according to the method of Doumas et al. (1971). Plasma globulin concentration was calculated by the difference between total protein and albumin. Plasma glucose, urea nitrogen and creatinine were determined according to Fawcett and Soctt (1960). Uric acid was determined calorimetrically. 
Statistical analysis:

Data were statistically analyzed using One-Way Layout with Means Comparisons Procedure SAS (2003). Differences among means were tested by Duncan's Multiple Range Test (Duncan, 1955).

\section{RESULTS AND DISCUSSION}

\section{Productive performance}

Data presented in Table (4) showed that rabbits fed on diets 3 had significant differences $(\mathrm{P}<0.05)$ in final live weight, total weight gain, av. daily feed intake (ADFI) and feed conversion ratio (FCR) in comparison with control group. It was also observed that initial live weight and average daily weight gain had no significant difference $(\mathrm{P}>0.05)$ among all treatments.

Table (4): Effect of different levels of Sidr (ziziphus spina-christi L.) on some of growth performance during the experimental period (6 to 14 . weeks of age).

\begin{tabular}{|l|c|c|c|l|c|}
\hline \multirow{2}{*}{ Parameters } & \multicolumn{4}{|c|}{ Experimental diets, SL/kg } & \multirow{2}{*}{$\begin{array}{c}\text { Sig. } \\
\text { test }\end{array}$} \\
\cline { 2 - 5 } & $\begin{array}{c}\text { Diet1 } \\
\mathbf{( 0 . 0 g})\end{array}$ & $\begin{array}{c}\text { Diet2 } \\
\mathbf{( 1 0 . 0 g})\end{array}$ & $\begin{array}{c}\text { Diet3 } \\
\mathbf{( 2 0 . 0 g})\end{array}$ & $\mathbf{\pm S E}$ & \\
\hline Av. Initial live weight $(\mathrm{g})$ & 753.81 & 765.00 & 769.00 & 8.66 & NS \\
\hline Final live weight $(\mathrm{g})$ & $2366.25 \mathrm{c}$ & $2555.01 \mathrm{~b}$ & $2629.26 \mathrm{a}$ & 21.91 & \\
\hline Total weight gain $(\mathrm{g})$ & $1612.44 \mathrm{c}$ & $1790.01 \mathrm{~b}$ & $1860.26 \mathrm{a}$ & 18.36 & \\
\hline Av. Daily weight gain $(\mathrm{g})$ & 28.79 & 31.96 & 33.22 & 1.12 & NS \\
\hline Av. Daily feed intake(g) & $85.34 \mathrm{~b}$ & $86.94 \mathrm{a}$ & $87.13 \mathrm{a}$ & 0.15 & \\
\hline Feed conversion ratio & $2.96 \mathrm{a}$ & $2.72 \mathrm{~b}$ & $2.62 \mathrm{~b}$ & 0.08 & \\
\hline
\end{tabular}

a,b and c: Means in the same row having different superscripts differ significantly $(\mathrm{P}<0.05)$.

These results are similar to those of Abdu et al., 2012 who reported that inclusion of ziziphus leaf meal in concentrate diet at 10-20\% levels gave best performance than when the leaf meal is included at higher levels to ram lambs. Also, Al-Mamary et al. (2001) showed that addition of low-tannin ( $1.4 \%$ catechin equivalent) in the diets of rabbits did not significantly change growth rate, feed intake or feed conversion ratio. Also, Struklec et al. (2001) did not observe palatability problems or anti-nutritional effects even at a dosage of 5\% condensed tannin. The present results are in disagreement with those of Douglas et al. (1993), reported that increasing the tanning level in 
the diet linearly depressed weight gains and feed conversion efficiencies of turkeys. However, McNabb et al (1998) and Barry and Duncan (1984) showed that the effect of tannins depends on the type and level of tannins, and dietary nutrients involved.

\section{Digestibility, feeding values and nitrogen balance}

Results of Table (5) showed that rabbits fed on diet 3 which contained $20 \mathrm{~g} \mathrm{Sidr}$ (ziziphus spina-christi L.) leaves /Kg diet recorded the highest DM, OM, CP, EE and NFE digestibility $(\mathrm{P}<0.05)$ than others, while rabbits fed control diet showed almost the lowest values $(P<0.05)$ of the digestibility of various feed components. Results of nutritive values as TDN and DCP as affected by SL supplementation are illustrated in (Table 5). It was observed that rabbits fed on diet 3 had significantly higher $(\mathrm{P}<0.05)$ of TDN and DCP compared with those fed on control diet. In contrary, Abdu et al. (2012) showed that there was a significant $(\mathrm{P}<0.05)$ depression on dry matter $(\mathrm{DM})$, organic matter (OM), neutral detergent fiber (NDF) and acid detergent fiber (ADF) digestibility, as the ziziphus spina christi leaf meal inclusion in the supplementary Yan kasa lambs diet.

Different hypotheses explained the positive effect of low to moderate concentration of tannins as secondary metabolites identified in the ziziphus spina-christi could be responsible for antimicrobial and antifungal pathogens activity (Mohammed et al., 2012 and Mohammed et al., 2011). One of these, Tannins in low to moderate concentration bind cell walls protein of ruminal bacteria, preventing growth and protease activity [Asquith et al,1986] and making nutritional proteins unavailable for them (Junior and Zanil 2000), (Asquith et al.,1986). That increase flow of non-ammonia nitrogen and essential amino acid from the rumen (Egan and Ulyatt, 1980; Barry and Manley, 1984; Waghrn et al., 1987) and cecum in rabbits. It is known that rabbits eat their faeces and hence drive substantial amounts of microbial proteins from such diets (Al-Mamary et al., 2001). However, that could lead to further digestibility of the re-ingested tannin-complexes formed along the digestive tract, but this is not well known and may require further investigation. Also, Tannins partially cover the mucus membrane of the gut and thereby a barrier against toxins (Chung et al., 1998) is used for the treatment of stomach discomfort and urinary infections (Adzu et al., 2003) that could lead to improve the health status of the rabbits.

The results revealed that no significant differences in nitrogen intake were detected between rabbits fed experimental diets (Table 5) on three 
UTILIZATION OF Ziziphus spina-christi LEAVES IN RABBIT'S RATIONS 435

Table (5): Effect of different levels of Sidr (ziziphus spina-christi L.) on digestion coefficients (\%), nutritive values $(\%)$ and nitrogen balance of experimental diets.

\begin{tabular}{|c|c|c|c|c|c|}
\hline \multirow[b]{2}{*}{ Items } & \multicolumn{3}{|c|}{ Experimental diets, SL/kg } & \multirow[t]{2}{*}{$\pm \mathrm{SE}$} & \multirow{2}{*}{$\begin{array}{l}\text { Sig. } \\
\text { test }\end{array}$} \\
\hline & $\begin{array}{l}\text { Diet1 } \\
(0.0 g)\end{array}$ & $\begin{array}{c}\text { Diet2 } \\
(10.0 \mathrm{~g})\end{array}$ & $\begin{array}{l}\text { Diet3 } \\
(20.0 g)\end{array}$ & & \\
\hline \multicolumn{6}{|l|}{ Digestion coefficients (\%) } \\
\hline DM & $67.56 \mathrm{c}$ & $69.26 \mathrm{~b}$ & $70.46 a$ & 0.33 & \\
\hline $\mathrm{OM}$ & $67.67 \mathrm{c}$ & $69.67 \mathrm{~b}$ & $71.20 \mathrm{a}$ & 0.44 & \\
\hline $\mathrm{CP}$ & $73.46 \mathrm{c}$ & $76.19 \mathrm{~b}$ & $77.76 \mathrm{a}$ & 0.51 & \\
\hline $\mathrm{CF}$ & $58.30 \mathrm{~b}$ & $59.81 \mathrm{a}$ & $60.51 \mathrm{a}$ & 0.28 & \\
\hline EE & $70.34 \mathrm{c}$ & $73.78 \mathrm{~b}$ & $76.41 \mathrm{a}$ & 0.68 & \\
\hline NFE & $67.96 b$ & $68.62 b$ & $70.70 \mathrm{a}$ & 0.36 & \\
\hline \multicolumn{6}{|l|}{ Nutritive value (\%) } \\
\hline TDN & $63.57 \mathrm{c}$ & $64.57 \mathrm{~b}$ & $66.27 \mathrm{a}$ & 0.32 & \\
\hline DCP & $12.90 \mathrm{~b}$ & $13.23 \mathrm{ab}$ & $13.49 \mathrm{a}$ & 0.11 & \\
\hline \multicolumn{6}{|l|}{ Nitrogen balance } \\
\hline Nitrogen intake (g day-1) & 2.44 & 2.51 & 2.54 & 0.05 & NS \\
\hline Excreted nitrogen through faeces (g day-1) & $0.95 \mathrm{a}$ & $0.91 \mathrm{a}$ & $0.83 \mathrm{~b}$ & 0.02 & \\
\hline Excreted nitrogen through urine (g day-1) & $0.44 \mathrm{a}$ & $0.37 \mathrm{~b}$ & $0.27 \mathrm{c}$ & 0.02 & \\
\hline Total excreted nitrogen (g day-1) & $1.39 \mathrm{a}$ & $1.28 \mathrm{~b}$ & $1.10 \mathrm{c}$ & 0.04 & \\
\hline Nitrogen balance & $1.05 \mathrm{c}$ & $1.23 \mathrm{~b}$ & $1.44 \mathrm{a}$ & 0.05 & \\
\hline
\end{tabular}

a,b and c: Means in the same row having different superscripts differ significantly $(\mathrm{P}<0.05)$.

formulated diets containing 0,10 and $20 \mathrm{~g} \mathrm{SL} / \mathrm{Kg}$ diet. Rabbits fed the diet 3 excreted the lowest amount $(\mathrm{P}<0.05)$ of nitrogen through feces and urine.

Rabbits fed the diet 3 recorded the best nitrogen balance $(\mathrm{P}<0.05)$ than others, which followed by those fed diet 2 and control diet, respectively. Similar trends have been observed by Al-Mamary et al (2001) who found that addition of low-tannin sorghum grains to the rabbit diet did not significantly have any effect on faecal nitrogen excretion and nitrogen retention with respect to the control diet. However, in their experiment, they also observed that the addition of high tannin sorghum grains significantly increased faecal nitrogen output and reduced nitrogen retention. In disagreement with our results $\mathrm{Abdu}$ et al. (2012) found that feeding different levels (0, 10, 20, 30, and 40\%) ziziphus spina christi leaf meal containing diets significantly $(\mathrm{P}<0.05)$ influenced nitrogen utilization. The positive effects of tannins on protein utilization have practical importance because problems associate with 
extensive proteolysis and /or de-amination in the rumen will be avoided by binding of tannins with proteins (Beever et al., 1989).

\section{Cecum activity}

The caecum activity and micro flora count of the rabbits in experimental trial are presented in Table 6. There were no differences ( $P>0.05)$ between treatments in caecum weigh, caecum length and TVFA. Ammonia concentrations were found within the range $22.71-27.88 \mathrm{mg} / \mathrm{dl}$, the $\mathrm{NH}_{3}-\mathrm{N}$ value of group 1 was significantly $(\mathrm{P}<0.05)$ higher than others.

The $\mathrm{pH}$ value of the caecum is usually about 6.0- 7.0 around growing rabbits depending on microbial activity and feeding pattern (Cheeke, 1987 and Fekete, 1990). Increasing sidr leaves level resulted in more fermentation in the cecum, thus reduced cecum $\mathrm{pH}$ as a result of increasing $(\mathrm{P}>0.05)$ VFA production. Caecal $\mathrm{pH}$ varies inversely to the increase in VFA concentration. These values are in general agreement with those obtained by García et al. (2002). However, decreasing NH3-N concentration and $\mathrm{pH}$ and the increasing of VFA in the cecum may be attributed to increasing digestion of all nutrients (Table 5) accordingly, that leads to decrease the proteolytic capacity of caecal microorganisms, as occurs in the rumen (Waghorn et al., 1987). Also, decreasing NH3-N concentration may be attributed to the conversion of ammonia- $\mathrm{N}$ into microbial protein for the benefit of rabbits which characterized by the pseudo-rumination.

The total anaerobic bacteria count in control group was higher $(\mathrm{P}<0.05)$ than others. However, rabbits of groups 3 and 2 recorded the highest $(\mathrm{P}<0.05)$ total anaerobic cellulolytic bacteria count values than group 1 . This may be due to the decreasing of the cecum $\mathrm{pH}$ with increasing sidr leaf level when compared to the control diet. Also, these results may be due to that tannins have general antimicrobial and have been reported to prevent the development of bacteria by precipitating microbial protein (Asquith and Butlur1986). whereas, Korji, (2012) and Al-Mutairi et al. (2016) who found that the aqueous extract of ziziphus spina-christi leaves has shown significant antibacterial activity against Salmonella typhi, Proteus mirabilis, Shigella dysenteriae, E. coli, K. pneumonia, B. melitensis, Bordetella bronchiseptica and $P$. aeruginosa in comparison with eight antibiotics. Bennegadi et al. (2003) found that cellulolytic bacteria represented $<7 \%$ of total bacteria, with a predominance of $R$. flavefaciens and R.albus, respectively, for conventional and specific pathogen free rabbits. It is clear to notice that incorporating sider 
Table 6: Caecum activity and micro flora count as affected by feeding different levels of sidr (ziziphus spina-christi) for growing rabbits.

\begin{tabular}{|c|c|c|c|c|c|}
\hline \multirow[b]{2}{*}{ Items } & \multicolumn{3}{|c|}{ Experimental diets, SL/kg } & \multirow[t]{2}{*}{$\pm \mathrm{SE}$} & \multirow{2}{*}{$\begin{array}{l}\text { Sig. } \\
\text { test }\end{array}$} \\
\hline & $\begin{array}{l}\text { Diet1 } \\
(0.0 g)\end{array}$ & $\begin{array}{l}\text { Diet2 } \\
(10.0 g)\end{array}$ & $\begin{array}{l}\text { Diet3 } \\
(20.0 g)\end{array}$ & & \\
\hline Caecum weight, $\mathrm{g}$ & $169.77 \mathrm{a}$ & $169.43 \mathrm{a}$ & $169.73 \mathrm{a}$ & 0.0 .75 & \\
\hline Caecum length, $\mathrm{cm}$ & $11.78 \mathrm{a}$ & $11.46 \mathrm{a}$ & $11.90 \mathrm{a}$ & 0.17 & NS \\
\hline TVFA (meq. / dL cecal juice) & $6.01 \mathrm{a}$ & $6.18 \mathrm{a}$ & $6.23 a$ & 0.10 & NS \\
\hline NH3-N (mg\dL cecal juice) & $27.88 \mathrm{a}$ & $22.88 b$ & $22.71 \mathrm{~b}$ & 0.72 & \\
\hline Caecum pH & $5.80 \mathrm{a}$ & $5.71 \mathrm{~b}$ & $5.69 \mathrm{~b}$ & 0.02 & \\
\hline $\begin{array}{l}\text { Total anaerobic bacteria count } \\
\left(\log ^{-1} \mathrm{cfu} / \mathrm{ml}\right)\end{array}$ & $7.76 \mathrm{a}$ & $6.42 b$ & $6.12 \mathrm{c}$ & 0.21 & \\
\hline $\begin{array}{l}\text { Total Anaerobic cellulolytic } \\
\text { bacteria count }\left(\log ^{-1} \mathrm{cfu} / \mathrm{ml}\right)\end{array}$ & $6.19^{\mathrm{b}}$ & $6.73 \mathrm{a}$ & $6.80 \mathrm{a}$ & 0.09 & \\
\hline
\end{tabular}

a,b,c Means in the same row with different superscripts are significantly different $(\mathrm{P}<0.05)$.

leaves in rabbit diets stimulating the maturation of cecal flora especially cellulolytic bacteria, which secretes enzymes capable of hydrolyzing the cellulose as the main components of dietary fiber.

\section{Blood parameters}

It was interest to note that as sidr leaves level increases total protein albumin, globulin and glucose levels in blood plasma of rabbits within normal range according to (Steven $(1974)$ significantly $(\mathrm{P}<0.05)$ decreases (Table 7). The obtained results of this study were comparable to the report of Mitruka and Rawwnssely (1977) who reported a range of glucose was $43.02-99.9 \mathrm{mg} / \mathrm{dl}$ and Jackson and Cockcroft (2002) (43.2-72 mg/dl). Plasma glucose is an indication of carbohydrate metabolism in high energy diets (Coles 1980). The current results are in harmony with those obtained by Glombitza et al. (1994) who demonstrated that the butanol extract (saponin fraction) of ziziphus spinachristi leaves or its main saponin glycoside improved glucose utilization in diabetic rats. Also, Michel et al. (2011) reported that Oral administration of $200 \mathrm{mg} / \mathrm{kg} \mathrm{B}$.W of ziziphus spina-christi leaf extract diet-diabetic rats for 28 days resulted in significant reduction in blood glucose level together with significant rise in plasma insulin. Vessal et al. (2003) suggested that quercetin has proven to be beneficial in decreasing blood glucose concentration, promoting regeneration of the pancreatic islets, as shown by increased number of islet cells, and increasing insulin release in diabetic rats. 
However, urea nitrogen, uric acid and creatinine values were also significantly $(\mathrm{P}<0.05)$ higher in the control group than others. Lower blood urea indicates superior protein quality in group of rabbits received 10 and $20 \mathrm{~g}$ / Kg SL diet this had earlier been reported by Eggun, (1970), that high level of blood urea indicated poor protein quality, the high level of plasma urea might be attributed to excessive tissue protein catabolism associated with protein deficiency (Odunye and Adedevon 1976). These results are parallel with Wada et al (2014) who found that as ziziphus mucronata level increase (0 - 5\%-10\%$15 \%)$ in Yan kasa ram's diet urea and creatinine decreased. Creatinine values in this study were significantly $(\mathrm{p}<0.05)$ among the treatments, whereas diet 1 have the highest value of $0.65 \mathrm{mg} / \mathrm{dl}$ which is a slightly lower than (1.41-24.40 $\mathrm{mmol} / \mathrm{L}$ ) reported by (Özkan et al., 2012). This observation suggested that there's no muscle waste and that the rabbits did not survive at the expense of their body reserves (Ologhobo, 1992). So, this is an indication that the dietary protein was well utilized by the rabbits in each treatment group as earlier reported elsewhere (Eggun 1970, Ross et al., 1978).

Table (7): Effect of different levels of sidr (Ziziphus spina-christi) on blood biochemical ( Within normal range, Steven of growing rabbits.

\begin{tabular}{|c|c|c|c|c|c|}
\hline \multirow[b]{2}{*}{ Items } & \multicolumn{3}{|c|}{ Experimental diets, SL/kg } & \multirow[t]{2}{*}{$\pm \mathrm{SE}$} & \multirow{2}{*}{$\begin{array}{l}\text { Sig. } \\
\text { test }\end{array}$} \\
\hline & $\begin{array}{l}\text { Diet1 } \\
(0.0 \mathrm{~g})\end{array}$ & $\begin{array}{c}\text { Diet2 } \\
(\mathbf{1 0 . 0 g})\end{array}$ & $\begin{array}{c}\text { Diet3 } \\
(20.0 \mathrm{~g})\end{array}$ & & \\
\hline Total Protein, (g/dl) & $6.39 \mathrm{a}$ & $5.72 \mathrm{ab}$ & $5.39 \mathrm{~b}$ & 0.16 & \\
\hline Albumin, (g/dl) & $3.97 \mathrm{a}$ & $3.03 b$ & $3.10 \mathrm{~b}$ & 0.14 & \\
\hline Globuline, $(\mathrm{g})$ & $2.42 \mathrm{~b}$ & $2.69 \mathrm{a}$ & $2.29 \mathrm{c}$ & 0.05 & \\
\hline Glucose, (mg/dl) & $85.77 \mathrm{a}$ & $81.66 \mathrm{~b}$ & $80.94 b$ & 0.63 & \\
\hline Urea nitrogen, $(\mathrm{mg} / \mathrm{dl})$ & $26.22 \mathrm{a}$ & $22.63 b$ & $21.01 \mathrm{c}$ & 0.61 & \\
\hline Uric acid, $(\mathrm{mg} / \mathrm{dl})$ & $0.48 \mathrm{a}$ & $0.39 \mathrm{~b}$ & $0.37 \mathrm{~b}$ & 0.02 & \\
\hline Creatinine, (mg/dl) & $0.65 \mathrm{a}$ & $0.52 b$ & $0.50 \mathrm{~b}$ & 0.02 & \\
\hline
\end{tabular}

$a, \mathrm{~b}$ and $\mathrm{c}$ : Means in the same row having different superscripts differ significantly $(\mathrm{P}<0.05)$.

\section{Carcass traits:}

Table (8) shows the carcass characteristics of rabbit groups fed the experimental diets. The results indicated that increase in sider leaves supplementation in the diet, significantly $(\mathrm{P}<0.05)$ improved the dressing percentages of slaughter rabbits.

Whereas, the rabbits fed diets containing 0,10 and $20 \mathrm{~g} \mathrm{SL} / \mathrm{Kg}$ diet recorded the dressing percentages of 58.11, 60.89 and $63.03 \%$, respectively. The results indicated that head, heart, kidney fat, spleen, lung and cecum 
Table (8): Carcass characteristics of rabbit groups fed the experimental diets.

\begin{tabular}{|l|c|c|c|c|c|}
\hline \multirow{2}{*}{ Items } & \multicolumn{2}{|c|}{ Experimental diets, SL/kg } & \multirow{2}{*}{ SE } & \multirow{2}{*}{$\begin{array}{c}\text { Sig. } \\
\text { test }\end{array}$} \\
\cline { 2 - 4 } & $\begin{array}{c}\text { Diet1 } \\
\mathbf{( 0 . 0 g )}\end{array}$ & $\begin{array}{c}\text { Diet2 } \\
\mathbf{( 1 0 . 0 g )}\end{array}$ & $\begin{array}{c}\text { Diet3 } \\
\mathbf{( 2 0 . 0 g )}\end{array}$ & & \\
\hline Pre-slaughter weight (g) & $2366.25 \mathrm{~b}$ & $2555.01 \mathrm{a}$ & $2629.26 \mathrm{a}$ & 33.60 & \\
\hline Hot carcass weight (g) & $1374.55 \mathrm{c}$ & $1555.23 \mathrm{~b}$ & $1657.22 \mathrm{a}$ & 34.31 & \\
\hline Dressing (\%) & $58.11 \mathrm{c}$ & $60.89 \mathrm{~b}$ & $63.03 \mathrm{a}$ & 0.56 & \\
\hline Fur (\%) & $7.08 \mathrm{~b}$ & $7.43 \mathrm{ab}$ & $7.65 \mathrm{a}$ & 0.09 & $\mathrm{NS}$ \\
\hline Head (\%) & 4.51 & 4.68 & 4.74 & 0.07 & $\mathrm{NS}$ \\
\hline Liver (\%) & $2.12 \mathrm{~b}$ & $2.41 \mathrm{a}$ & $2.50 \mathrm{a}$ & 0.06 & \\
\hline Heart (\%) & 0.23 & 0.23 & 0.23 & 0.01 & $\mathrm{NS}$ \\
\hline Kidney (\%) & $0.52 \mathrm{~b}$ & $0.60 \mathrm{a}$ & $0.61 \mathrm{a}$ & 0.01 & \\
\hline Kidney fat (\%) & 0.23 & 0.28 & 0.29 & 0.01 & $\mathrm{NS}$ \\
\hline Spleen (\%) & 0.044 & 0.045 & 0.045 & 0.001 & $\mathrm{NS}$ \\
\hline Lung (\%) & 0.52 & 0.54 & 0.54 & 0.01 & $\mathrm{NS}$ \\
\hline Cecum [\% & 6.68 & 6.77 & 6.88 & 0.07 & $\mathrm{NS}$ \\
\hline Edible giblets (\%) & $2.86 \mathrm{~b}$ & $3.24 \mathrm{a}$ & $3.44 \mathrm{a}$ & 0.08 & \\
\hline Total edible parts (\%) & $60.97 \mathrm{c}$ & $64.13 \mathrm{~b}$ & $65.97 \mathrm{a}$ & 0.56 & \\
\hline Total non-edible parts (\%) & $39.03 \mathrm{a}$ & $35.87 \mathrm{~b}$ & $34.03 \mathrm{c}$ & 0.56 & \\
\hline
\end{tabular}

$a, \mathrm{~b}$ and $\mathrm{c}$ : Means in the same row having different superscripts differ significantly $(\mathrm{P}<0.05)$.

Weight of hot carcass including head as percentage of pre-slaughter weight, Edible giblets $(\%)=\{$ Liver $(\mathrm{g})+$ Kidney $(\mathrm{g})+$ Heart $(\mathrm{g}) /$ Pre-slaughter weight $(\mathrm{g})\}$ x 100,

Total edible parts $(\%)=\{$ Carcass weight $(\mathrm{g})+$ Weight of edible giblets $(\mathrm{g}) /$ Pre-slaughter weight $(\mathrm{g})\}$ x 100 .

percentages were unaffected significantly by treatments. However, it was noted that total edible parts $(\%)$ were improved significantly $(\mathrm{P}<0.05)$ with increasing dietary sider leaves level. Under normal physiological conditions, the condensed tannins are not absorbed into the blood streams, therefore, they are not likely to damage organs such as the liver, kidney, spleen, etc., as has been the case for hydrolysable tannins (McSweeney et al., 2001).

Conclusively, these increments in live body weight and body weight gain may be attributed to increasing digestion of all nutrients, decreasing $\mathrm{pH}$ and count of pathogenic bacteria which have a role on decreasing diarrhea at sidr leaves levels 10 and $20 \mathrm{~g} / \mathrm{Kg}$ SL diet. Also, decreasing NH3-N concentration and the increasing of VFA in the cecum, accordingly, improving the nutrients utilization may be attributed to the conversion of ammonia-N into microbial protein for the benefit of rabbits which 
characterized by the pseudo-rumination. Therefore, the present results proved that ziziphus spina-christi leaves could be used in feeding of growing rabbits up to $20 \mathrm{~g} / \mathrm{SL} / \mathrm{kg}$ diets as natural growth promoters without any adverse effects on rabbit performance.

\section{REFERENCES}

Abdel-Galil, F. M. and El-Jissry M. A. (1991). Cyclopeptide alkaloids from Ziziphus spina-christi. Phytochemistry, 30(4); Page 1348-1349.

Abdu, S.B., Ehoche, O.W., Adamu, A.M., Bawa, G.S., Hassan, M.R., Yashim, S.M. and Adamu, H.Y. (2012). Effect of Varying Levels of Ziziphus (Ziziphus mauritiana) Leaf Meal Inclusion in Concentrate Diet on Performance of Growing Yankasa Ram Lambs Fed Maize Stover Basal Diet. Iranian Journal of Applied Animal Science, (2012) 2(4), 323-330.

Adzu B., Amos S., Amizan, M.B., Gamaniel, K. (2003). Evaluation of the anti-diarrhoeal effects of Ziziphus spina-christi stem bark in rats. Acta Trop; 87(2):245-250.

Al Mamary, M., Molham, A., Abdulwali, A. and Al-Obeide, A. (2001). In vivo effect of dietary sorghum tannins on rabbit digestive enzyme and mineral absorption. Nutritional Research, 21: 1393-1401

Al-Mutairi, M. H., Sarah, Ali., Salah Mesalhy., Aly and Yousef Aldebasi. (2016). Antibacterial activity of sider (ziziphus spinachristi), leaves extract against selected pathogenic bacteria. European Journal Of Pharmaceutical And Medical Research Ejpmr, 2016,3(5),138-144.

AOAC (2000). Association of Official Analytical Chemists. Official Methods of Analysis, $17^{\text {th }} \mathrm{Ed}$. AOAC, Washington, DC, USA.

Asquith, T.N, Butler, L.G. (1986). Interaction of condensed Tannins with selected proteins. Phytochemistry; 25(7):1591- 1593.

Barry, T .N and Duncan, S. J. (1984). The role of condensed tannins in nutritional value of lotus pendunculotus for sheep I. Voluntary intake. British Journal of Nutrition, 51: 485-491

Barry, T.N. and Manley, T.R. (1984). The role of condensed tannins in the nutritional value of Lotus pedunculatus for sheep 2: Quantitative digestion of carbohydrate and protein. B r. J. Nutr., 5l: 493-504. 
UTILIZATION OF Ziziphus spina-christi LEAVES IN RABBIT'S RATIONS 441

Beever, D.E., Gill, M. and Sutton, J.D. (1989). Limits to animal production with high forage diets. J. Anim. Sci., 67 (suppl. 1): 298 (Abstract).

Bennegadi, N., Fonty, G., Millet, L., Gidenne, T., Licois, D. (2003). Effects of age and dietary fibre level on caecal microbial communities of conventional and specific pathogen-free rabbits. Microbial Ecology in Health and Disease, 5. 23- 32.

Bomba, A., Jonecová, Z., Koščová, J., Nemcová, R., Gancarčíková, S., Mudroňová, D., Sciranková, L., Buleca, V., Lazar, G., Pošivák, J., Kaštel', R. and Mareková, M. (2006). The improvement of probiotics efficacy by synergistically acting components of natural origin: a review. Biologia, Bratislava, Section Cellular and Molecular Biology, 61 (6): 729.

Kim, H.U. and Goepfert, J.M. (1971). Enumeration and identification of bacillus cereeus in foods. 1,24-hours presumptive test edium. Appl. Microbiol., 22:581-587.

Cheeke, P.R. (1987). Rabbit Feeding and Nutrition. Academic Press, INC.

Chung, K. T., Wong, T. Y., Wei, C. L., Huang, Y. W. and Lin, Y. (1998). Tannins and Human Health: A Review. Critical Reviews in Food Science and Nutrition, 38, 421-464.

Coles, E.H. (1980). Veterinary clinical pathology, 3rdEdn., W.B. Sanders Co. Philadelphia, pp 10-20.

Combes, S., Fortun-Lamothe, L., Cauquiland, L. and Gidenne, T. (2013). Engineering the rabbit digestive ecosystem to improve digestive health and efficacy. Animal, 7: 1429-1439.

De Blas, J. C. and Garvey, J. P. (1975). A note on the retention of energy and nitrogen in rabbits. Animal Production, 21, 345-347.

Difco Laboratories Incorporated (1984). Difco: manual of dehydrated culture media and reagents for microbiological and clinical laboratory procedure, 10th Ed. Michigan, USA.

Douglas, J. H., Sullivan, T. W., G onzalez, N. J. and Beck, M. M.(1993). Differential Age response of turkeys to protein and sorghum tannin levels. Poult. Sci. 72:1944-1951.

Doumas, B.T., Watson, W.A. and Biggs, H.G. (1971). Albumin standards and the measurement of serum albumin with bromcresol green. Clin. Chem. Acta. 31:87-96.

Duncan, D.B. (1955). Multiple ranges and multiple F test. Biometrics, 11:1- 42. 
Egan, A.R. and ulyatt, M.J. (1980). Quantitative digestion of fresh herbage by sheep:V I utilization of nitrogen in five herbages. J. Agric. Sci., 94: 47.

Eggun, B.O. (1970). Blood urea measurement as technique for assessing protein quality. Br. J. Nutr., 48: 225-233.

Fawcett, J.K. and Scott, J.E. (1960). Determination of urea. Journal of Clic. Path., 13:156-159.

Fekete, S. and Gippert, T. (1986). Digestibility and nutritive value of nineteen important feedstuffs for rabbits. J. Appli. Rabbit Res., 9 (3): 103-108.

Fekete, S. (1990). Physiological and biological charac teristics of rabbits [in Hungarian]. In: Rabbit Health (ed.: Vetési F.), Mezıgazdasági Kiadó, Budapest, 36-61.

Garcia J., Nicodemus N., Carabano R., De Blas J.C. (2002). Effect of inclusion of defatted grape seed meal in the diet on digestion and performance of growing rabbits. J. Anim. Sci., 80, 162-170.

Glombitza, K.W., Mahran, G.H., Mirhom, Y.M., Michel, C.G., Motawi, T.K. (1994). Hypoglycemic and antihyperglycemic effects of Ziziphus spina-christi in rats. Planta Medica, 60, 244-247.

Jackson, G.G.P. and Cockcroft, D. P. (2002). Clinical examination of farm animals; Appendix 3, Laboratory Reference Values: Biochemistry. Kajian Vet. (Malaysia Singapore), 7(2):63-66.

Junior, A and Zanil, C. 2000. Biological screening of Brazilian meditional plants. Braz J Sci; 95:367-373.

King-thom, ch., tit yee wong., cheng wei., yao-wen huang and yuan lin. (1998). Tannins and Human Health: A Review Critical review in food science and nutrition volume 38, issue 6 pages $421-464$

Korji, S. H. A. (2012). Inhibition of nitrate reductase production from Gramnegative bacteria using Ziziphus spina-christi extract and comparing with some antibiotics. Iraqi J. Agric. Sci., 43(2):144-150.

Lebas, F. (2004). Reflections on rabbit nutrition with a special emphasis on feed ingredients utilization. Paper presented at: the 8th World Rabbit Congress; Sep 7-10; Puebla, Mexico. p. 686-736.

Lelkes, L. and Chang, Ch. (1987). Microbial Dysbiosis in Rabbit Mucoid Enteropathy, Laboratory Animal Science. 37. 6. 757-764.

Makkar, H. P. S. (2003): Effects and fate of tannins in ruminant animals, adaptation to tannins, and strategies to overcome detrimental effects of feeding tannin-rich feeds. Small Rumin. Res., 49:241-56. 
UTILIZATION OF Ziziphus spina-christi LEAVES IN RABBIT'S RATIONS 443

McNabb, W. C., Peters, J.S., Foo, L. Y., Waghorn, G. C. and Jackson, F. S. (1998). Effect of condensed tannins prepared from several forages on the in vitro precipitation of ribulose 1.5 biosphophate carboxylase (rubisco) protein and its digestion by trypsin (EC 2.4.21.4) and chymotrypsin (EC2.4.21.1) Journal of Science and Agriculture, 77: 201-212.

McSweeney, C.S., Palmer, B., McNeill, D.M., Krause, D.O. (2001). Microbial interactions with tannins: nutritional consequences for ruminants. Anim. Feed Sci. Technol., 91, 8393.

Meier, B., Sticher, O. and Julkunen-Tiitto, R. (1988). Pharmaceutical aspects of the use of willows in herbal remedies. Planta Medica, 54: 559-560.

Michela, Camilia. G., Demiana I. N., Ismail, Manal. F. (2011). Antidiabetic activity and stability study of the formulated leaf extract of Ziziphus spina-christi (L.) Willd with the influence of seasonal variation. Journal of Ethnopharmacology, 133 (2011) 53-62.

Mitruka, B. M. and Rawnsley, H. M. (1977). Clinical Biochemistry and Haematological Refrence vaues in Normal Experimental Animals. Massion Publishing. U. S. A. Pp 42-47.

Mohammed, G.T., Yesuf, H.B., Abdulrahman, F.I., Muazu, J., Yakubu, S.I., Sadiq, G.U. (2012). Antimicrobial and toxicological screening of the aqueous stem-bark extract of Ziziphus spina-christi (Linnaeus Desf). J Microbial Biotech Res; 2(2):337 - 342.

Mohammed, G.T., Yesufu, H.B., Khan, I.Z., Abdulrahman, F.I, Sandabe, U.K. (2011). Antimicrobial screening and effect of the pulp ethanol extracts of Ziziphus spina-christi (Linnaeus Desf) on some Biochemical parameters in Rats. Nigerian J of Exp and Appl Biology; 12(1):71 - 76.

Odunye, O. O. and Adedevon, B. K. (1976): Bio chemical values of apparently Normal Nigerian sheep. Nigerian veterinary Journal 5(1):43-50.

Ologhobo, A. D. (1992). Nutritive value of some tropical (West African) legumes for poultry. Journal of Applied Animal Research, 2: 93-104.

Orsonneau, J. L., Douet, P., Massoube, C., Lustenberger, P. and Bernard, S. (1989). An improved pyrogallol red-molybdate method for determining total urinary protein. Clin Chem., 35: 2233-2236. 
Özkan C., Kaya A., Akgül Y. (2012). Normal values of haematological and some biochemical parameters in serum and urine of New Zealand White rabbits. World Rabbit Sci., 2012, 20: 253 - 259.

Ross, J.G., Christie, G., Halliday, W.G and Jones, R.M. (1978): Haematological and blood chemistry comparison values for clinical pathology in poultry. Vet. Record, 102: 29-31.

SAS (1999). User's guid. Statistics. SAS Inst. Cary N. C. Releigh.

Snedecor, G.W., and W.G. Cochran. (1982). Statistical Methods. 2nd Ed. Iowa University, Press Ames, Iowa, USA

Steven H. W. (1974). The Biology of the Laboratory Rabbit. First Edition Hardcover: 552 pages; Publisher: Academic Pr.https://www.amazon. com / Biology-Laboratory.

Štruklec, M., Kermauner, A., Pirman, T., (2001). Die Wirkung einer zehnfachen empfohlenen Dosierung der Kastanientannine in der Kaninchenernärhrung während der Absetzperiode. 12. Arbeitstagung über Haltung und Krankheiten der Kaninchen, Pelztiere und Heimtiere. Ed. Deutsche Vet. Med. Gesellschaft e.V., Giessen, 57-66.

Tackholm, (1974). Students Flora of Egypt (Second ${ }^{\text {ed }}$ ) Publisher Cairo University, Giza, Egypt.

Vessal, M.l., Hemmati, M. and Vasei, M. (2003). Antidiabetic effects of quercetin in streptozocin-induced diabetic rats. Comp Biochem Physiology, 135C: 357-364.

Wada, N. I., Njidda, A. A., Adamu, M. and Chibuogwu, C. I. (2014). Variation in haematological and serum biochemical indices of sheep fed Ziziphus mucronata and Parkia biglobosa (A comparative study). G.J.B.A.H.S., Vol. 3(4):39-47.

Waghorn, G.C., Ulyatt, M. J., John, A. and Fisher, M.T. (1987). The effect of condensed tannins on the site of digestion of amino acids and other nutrients in sheep on Lotus corniculatusL. British Journal of Nutrition, 57, 115-126.

Warner, A.C.I. (1964). Production of volatile fatty acid in the rumen. 1: Method of measurements. Nutr. Abstr. Review, 34:339-410. 
UTILIZATION OF Ziziphus spina-christi LEAVES IN RABBIT'S RATIONS 445

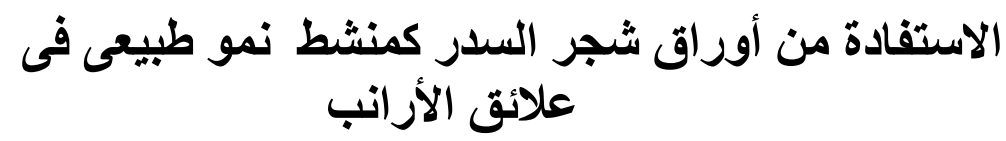

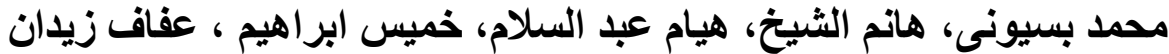

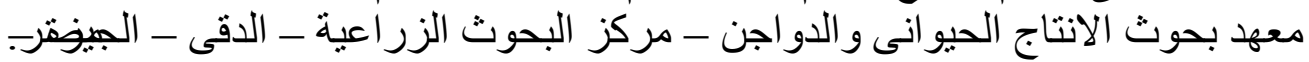

أجريت هذة التجربة بهدف در اسة تأثير استخدام اوراق شجر السدر كأحد مصادر منشطات النمو الطبيعية فى علائق الأرانب حيث تم تم استخدام 90 من 90 من ذكور

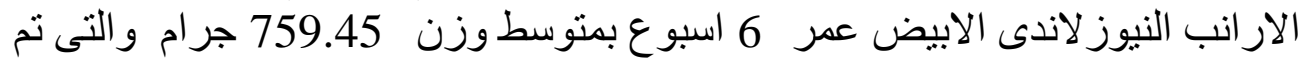

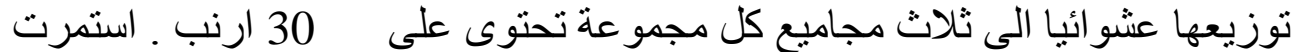

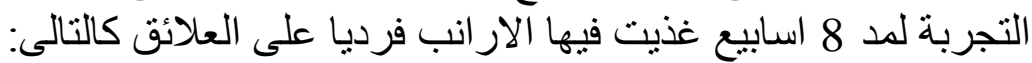

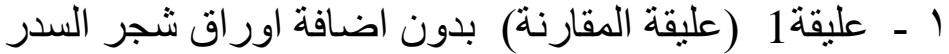

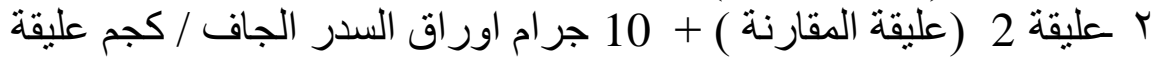

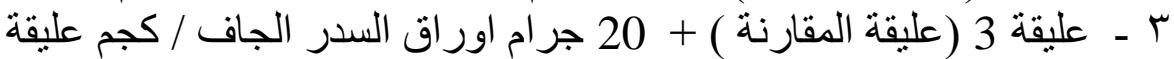

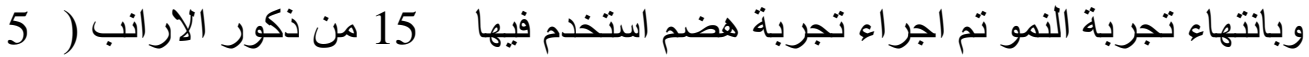

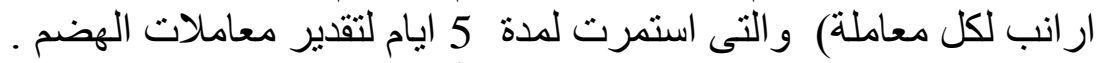
ويتحليل التتائج المتحصل عليها وليها احصائيا أتضح الاتئ:

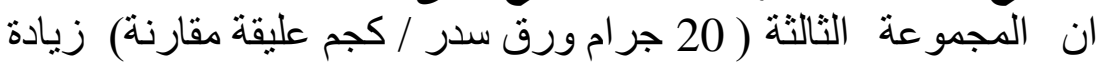

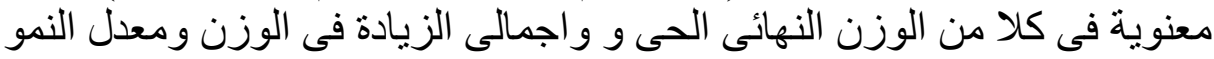

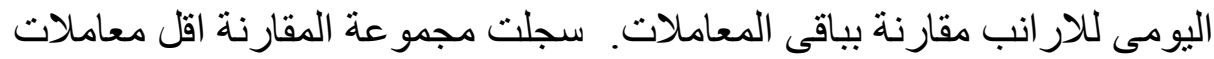

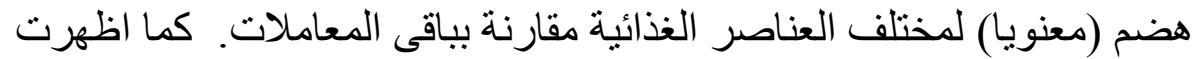
الار انب المغذاة على عليقة 3 افضل قيم معنوية لكلا من المركبات الكلية المهضونة

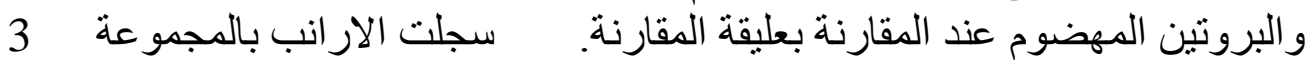

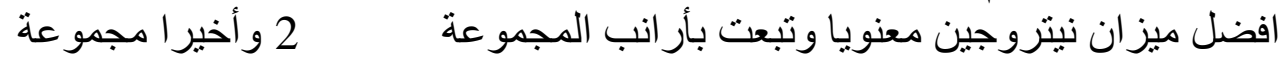

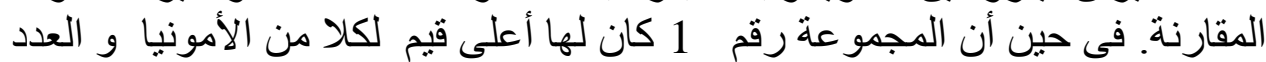

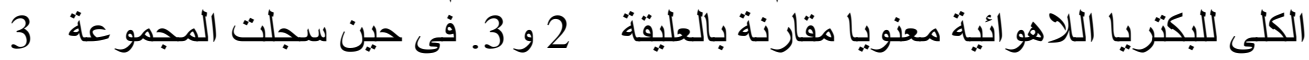

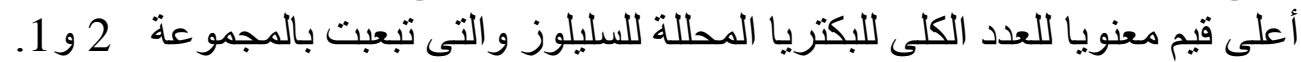

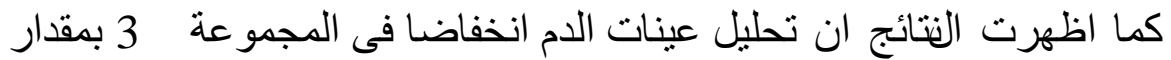

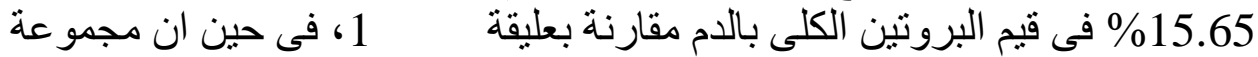

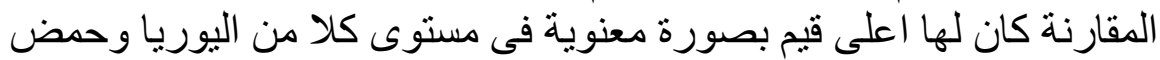




$$
\begin{aligned}
& \text { اليوريك و الكريتينين فى الدم مقارنة بعليقة الثالثة، كما تحسنت صفات الذبيحة فى }
\end{aligned}
$$

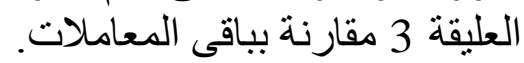

$$
\begin{aligned}
& \text { التوصية: ومن نتائج هذه الدر اسة بتضح امكانية استخدام المستويات المنخفضة من }
\end{aligned}
$$

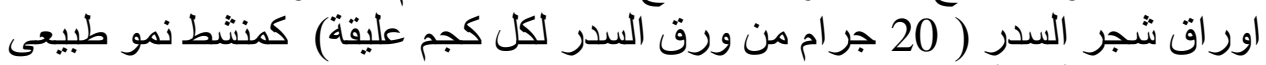

$$
\begin{aligned}
& \text { بدون ظهور أى تأثثرات سلبية على اداء الار انب النامية. }
\end{aligned}
$$

